\title{
Nutritional evaluation of differently processed plant protein sources on the performance of broiler chickens
}

\author{
Maidala, A. ${ }^{1 \star}$, Musa, G. ${ }^{2}$, Adamu L. ${ }^{1}$, Amaza B. I. ${ }^{1}$, Sudik, S. D. ${ }^{1}$ and Makinde, J. $0 .{ }^{1}$ \\ 1Department of Animal Science, Federal University Gashua, Yobe State, Nigeria. \\ ${ }^{2}$ Department of Agricultural Education, College of Education Kangere, P. M. B. 0316, Bauchi State, Nigeria. \\ *Corresponding author. Email: drmaidala@yahoo.com, aminumaidala@fugashua.edu.ng, aminunyari@gmail.com; Tel: +234 08035914479. \\ Copyright (C) 2021 Maidala et al. This article remains permanently open access under the terms of the Creative Commons Attribution License 4.0, \\ which permits unrestricted use, distribution, and reproduction in any medium, provided the original work is properly cited.
}

Received 2nd October, 2021, 2020; Accepted 17th November, 2021

\begin{abstract}
An eight-week feeding trial was conducted to assess four differently protein sources on performance of broiler chickens. Two hundred and fifty (250) day old unsex Anak 2000 broiler chicks were randomly allotted to four differently processed plant protein sources i.e. cooked soybean, salt treated African locust bean and sprouted Bambara nut with groundnut cake (GNC) based diet as control, the treatments were replicated five times (12 birds per replicate) in a Completely Randomized Block Design (CRBD). Results showed that daily feed intake, daily weight gain and feed conversion ratio were affected by different protein sources $(p<0.05)$ at starter, finisher and overall phase. The carcass characteristics showed that live weight (1988-2160 g), slaughter weight (1610-1965 g) and plucked weight (1600-1814 g) were affected by different protein sources $(p<0.05)$. The dressing percentage $(83.31-86.25 \%)$ are not affected by different protein sources $(p>0.05)$. The abdominal fat $(0.61-0.64 \%)$, gizzard $(1.61-1.77 \%)$, small intestine $(40.80-43.20 \mathrm{~cm})$ and large intestine $(141.80-201.60 \mathrm{~cm})$ were affected by the different protein sources $(p<0.05)$. All the prime cuts were significantly $(p<0.05)$ affected by the dietary protein sources. Total feed cost is highest in soya-bean based diet $(\mathbb{N} 379.30)$. The highest body weight $(4.53 \mathrm{~kg})$ is in soya bean-based diet. The feed cost per kg gain is highest in GNC based diet ( $\mathrm{N}$ 158.34) and lowest in soya bean based diet ( $\$$ 126.43). All the protein sources enhanced the growth performance of broiler chickens; however, soybean was more effective in enhancing the performance of broiler chickens.
\end{abstract}

Keywords: African locust bean, bambaranut, broilers, groundnut cake, performance, soybean.

\section{INTRODUCTION}

The high cost of feed is blamed on the competition between man and his livestock for the available grains which accounts for $70-85 \%$ cost of poultry production (Sanni and Ogundipe, 2005), this trend has account for low protein intake as a result of high cost of feeds. Food and agricultural organization of the united nation (FAO, 1993) recommended $35 \mathrm{~g}$ as the daily animal protein requirement for human being, but an average Nigerian consumes $3.24 \mathrm{~g}$ animal protein per day. It is obvious therefore that any effort targeted at reducing the cost of feeding will be one of the possible remedies, therefore there is need to find alternative protein sources in livestock feeding. Poultry production has been identified as one major means of solving problem of low protein intake in Nigeria (Maidala and Istifanus, 2012). The Nigerian poultry industry comprises about 180 million birds and is the second largest chicken population in Africa after South Africa (Sahel, 2015). The Nigerian poultry industry produced 650,000 tons of eggs and 300,000 tons of meat (FAOSTAT, 2018). However, feeding poultry presents a great challenge to farmers and nutritionists in Nigeria (Etuk et al., 2012) and several tropical countries. Protein is one of the classes of food that is needed by both man and animals to promote healthy growth at all stages of life. Farmers and feed millers more frequently used the conventional protein ingredients (like fullfat soybean and groundnut cake) in producing their feeds. Unfortunately, these feed ingredients have become scarce and oftentimes unavailable. This cost can be reduced by accommodating unconventional feed ingredients that have 
comparative nutrient potentials like the conventional ingredients such as Bambara nut (Maidala et al., 2011; Ani et al., 2012), African locust bean (Obun, 2007; Ari et al., 2012) and some of this unconventional protein sources proved promising in replacing conventional ones. Several researches were conducted in legumes to ascertain the effects of local processing on antinutritional factors and bioavailability of nutrients to broilers chickens. For instance, Maidala et al. (2013) and Maidala et al. (2017) conducted research on effects of local processing methods of differently processed soybean bean i.e., raw, cooked, sprouted, salt treated and sprouted soybean and concluded that cooked soybean was best for broiler production. Similarly, an experiment was conducted using differently processed African locust bean i.e., raw, cooked, sprouted, salt treated and sprouted African locust bean and concluded that salt treated African locust bean was best for broiler production (Maidala et al., 2018). Also, different processed Bambara nut was fed to broiler chickens i.e. raw, cooked, sprouted, salt treated and sprouted Bambara nut and concluded that sprouted Bambara nut was the best for broiler chicken's production (Maidala et al., 2015). It is against this background this study was design to test the performance of broiler chickens fed the differently processed plant proteins sources, to ascertain the best protein sources i.e. soybean (cooked), African locust bean (salt treated), Bambara nut (sprouted) with groundnut-based diet as control.

\section{MATERIALS AND METHODS}

The study was conducted at the School of Undergraduate, College of Education Azare, Bauchi State, Nigeria. Azare is located between latitude $11^{\circ} 15^{\prime}$ and $11^{\circ} 30^{\prime} \mathrm{N}$ and longitude $10^{\circ} 10 \mathrm{E}$ and $10^{\circ} 30^{\prime} \mathrm{E}$. The area is characterized by five (5) months of rainy season (April-September) and seven (7) months of dry season (October-March) (Bura, 2000). Mixed farming system is practiced by most of the farmers and low animal protein intake has been reported (Maidala et al., 2021).

Two hundred and fifty-day old Anak 2000 unsex broiler chicks were randomly allotted to four dietary treatments i.e., cooked soybean, salt treated African locust bean and sprouted Bambara nut with groundnut cake-based diet as control, the treatments were replicated five times (12 birds per replicate) in a Completely Randomized Block Design (CRBD).

\section{Experimental diets}

Four experimental diets were formulated to include cooked soybean, salt-treated African locust bean, sprouted Bambara nut and groundnut cake diet serving as control. The experimental diets were isocaloric and isonitrogenous. The experimental diets were analyzed for proximate composition (AOAC, 1990) at National Veterinary Research Institute Jos, Plateau State. Birds were provided with water and feed ad libitum. The birds were brooded for one week before assigned to experimental cages in deep litter system of management. The experiment lasted for eight weeks and adequate light were provided throughout the experiment. The parameters determined were daily feed intake and daily weight gain while feed conversion ratio and feed efficiency ratio were computed from the weight gain and feed intake values.

\section{Carcass evaluation and organ measurements}

At the end of the experiment, ten (10) birds from each treatment that is 2 birds per replicate were randomly selected for carcass analysis. The birds were fasted overnight and slaughter according to halal method (Maidala et al., 2020). Internal organs were removed and measured in grams and length of small intestine and large intestine were measured in centimetre. Individual organ was placed on an electric sensitive balance (Acculab) and the weight recorded. The length of the intestine and caeca were taken using metal meter rule. The weights of the various organs measured with the sensitive scale and expressed as a percentage of live weight.

\section{Data analyses}

The data obtained were subjected to analysis of variance (ANOVA) in a completely randomized block design (CRBD) (Steel and Torrie, 1980). Significant differences were separated using Duncan's multiple range tests (Duncan's 1955).

\section{RESULTS AND DISCUSSION}

The proximate composition of different processed protein is shown in Table 1. The percentage compositions of the experimental diets are shown in Tables 2 and 3 for starter and finisher phases respectively. The crude protein, metabolizable energy and other nutrients met the requirements of broiler chickens in the tropics (Maidala, 2015). The diets were formulated in consonance with the established recommendation for dietary energy and protein in broiler chicken raised in warm wet climates (Oluyemi and Roberts, 2000) and met the crude protein and energy requirement of broilers in the tropics. The proximate composition showed that crude protein ranged between $19.27 \%$ in sprouted Bambara nut to $41.98 \%$ in cooked soybean. Similarly, the crude fat was highest in cooked soybean while the nitrogen free extract was highest in sprouted Bambara nut (57.79). At the starter phase, daily feed intake of different processed protein sources (67.60-70.40 g) is higher compared to the ground- 
Table 1. Chemical composition (\%) of different protein sources fed to broiler chickens at the starter phase

\begin{tabular}{lcccc}
\hline & \multicolumn{4}{c}{ Diets } \\
\cline { 2 - 5 } Parameters & T1 [GNC] & $\begin{array}{c}\text { T2 [Soya bean } \\
\text { (Cooked)] }\end{array}$ & $\begin{array}{c}\text { T3 [ALBS (Salt- } \\
\text { treated)] }\end{array}$ & $\begin{array}{c}\text { T4 [Bambara nut } \\
\text { (Sprouted)] }\end{array}$ \\
\hline Dry matter & 89.21 & 94.00 & 95.20 & 93.69 \\
Crude protein & 40.12 & 41.98 & 24.57 & 19.27 \\
Crude fibre & 5.21 & 22.34 & 20.34 & 8.79 \\
Crude fat & 6.82 & 17.92 & 15.95 & 5.60 \\
Calcium & 4.23 & 2.95 & 5.40 & 0.18 \\
Phosphorus & 3.54 & 10.00 & 0.13 & 0.14 \\
Nitrogen free extract & 34.21 & 0.65 & 28.94 & 57.79 \\
\hline
\end{tabular}

Table 2. Ingredients and nutrient compositions (\%) of different protein sources fed to broiler chickens at the starter phase (1-5 weeks).

\begin{tabular}{lcccc}
\hline & \multicolumn{4}{c}{ Diets } \\
\cline { 2 - 5 } Parameters & T1 [GNC] & $\begin{array}{c}\text { T2 [Soya bean } \\
\text { (Cooked)] }\end{array}$ & $\begin{array}{c}\text { T3 [ALBS (Salt- } \\
\text { treated)] }\end{array}$ & $\begin{array}{c}\text { T4 [Bambara } \\
\text { nut (Sprouted)] }\end{array}$ \\
\hline Maize & 52.05 & 45.06 & 37.52 & 46.32 \\
Soybean & - & 36.04 & 17.43 & 6.95 \\
Bambaranut & - & - & - & 27.82 \\
Locust bean & - & - & 26.15 & - \\
Groundnut cake & 29.05 & - & - & - \\
Wheat offal & 10.00 & 10.00 & 10.00 & 10.00 \\
Fishmeal & 5.00 & 5.00 & 5.00 & 5.00 \\
Limestone & 1.00 & 1.00 & 1.00 & 1.00 \\
Bone meal & 2.00 & 2.00 & 2.00 & 2.00 \\
Sodium chloride & 0.25 & 0.25 & 0.25 & 0.25 \\
Lysine & 0.20 & 0.20 & 0.20 & 0.20 \\
Methionine & 0.20 & 0.20 & 0.20 & 0.20 \\
Vitamin/mineral premix * & 0.25 & 0.25 & 0.25 & 0.25 \\
Total & 100.00 & 100.00 & 100.00 & 100.00 \\
& & & & \\
Nutrient composition (calculated) & & & & \\
Crude protein (\%) & 23 & 23 & 23 & 23 \\
Metabolisable energy (kcal/kg) & 2800 & 2800 & 2800 & 5.66 \\
Ether extract (\%) & 6.80 & 10.84 & 7.19 & 5.07 \\
Crude fibre (\%) & 3.57 & 4.08 & 5.25 & 0.92 \\
Calcium (\%) & 0.90 & 0.92 & 0.92 & 1.2 \\
Available phosphorus \% & 1.2 & 1.2 & 1.2 & \\
\hline Not: Each Klon
\end{tabular}

Note: * Each kilogram contains; vit. A, 10,000,000 IU, vit. $D_{3} 2,000,000 \mathrm{IU}$, Vit. E 23,000 mg, Vit. $\mathrm{K}_{3} 2.000 \mathrm{mg}$, Vit, $\mathrm{B}_{1} 1,800 \mathrm{mg}$, Panthothenic Acid 7,500 mg, Vit. $B_{6} 3,000$ mg, Vit. $B_{12} 15 \mathrm{mg}$, Folic acid $750 \mathrm{mg}$, Biotin $11260 \mathrm{mg}$, Choline Chloride $300,000 \mathrm{mg}$, Cobalt $200 \mathrm{mg}$, Copper 3,000mg, lodine 1,000 mg, iron 20,000 mg, Manganese 40,000mg, Selenium 200mg, Zinc 30,000 mg, Antioxidant $1,250 \mathrm{mg}$.

nut cake (GNC) diet (53.40 g) (Table 4). This could be attributed to adequate processing of different protein sources as adequate processing improves feed intake and utilization of feeds (Medugu et al., 2012; Akure et al., 2021). The daily weight gain was higher in the soybeanbased diet compared to other different processed protein sources and GNC based diet and this support the earlier report of Shaahu et al. (2011). The feed conversion ratio is better in the GNC based diet $(1.82 \mathrm{~g})$ followed by soybeanbased diet (1.89). This is attributed by direct relationship of feed intake and body weight gain, since feed is known to promote growth, helps in cell formation and repairs (Adeniyi, 2008). This finding is in harmony with the findings of Aguihe et al. (2011). The feed efficiency ratio was more 
Table 3. Ingredients and nutrient compositions (\%) of broiler finisher (21\% CP) diets containing different protein sources.

\begin{tabular}{lcccc}
\hline & \multicolumn{4}{c}{ Diets } \\
\cline { 2 - 5 } Parameters & T1 [GNC] & $\begin{array}{c}\text { T2 [Soya bean } \\
\text { (Cooked)] }\end{array}$ & $\begin{array}{c}\text { T3 [ALBS (Salt- } \\
\text { treated)] }\end{array}$ & $\begin{array}{c}\text { T4 [Bambara nut } \\
\text { (Sprouted)] }\end{array}$ \\
\hline Maize & 54.06 & 45.06 & 50.00 & 44.00 \\
Soybean & - & 31.04 & 6.75 & 6.28 \\
Bambaranut & - & - & & 25.82 \\
Locust bean & - & - & 20.25 & - \\
Groundnut & 23.03 & - & 15.00 & 15.00 \\
Wheat offal & 15.00 & 15.00 & 5.00 & 5.00 \\
Fishmeal & 5.00 & 5.00 & 1.00 & 1.00 \\
Limestone & 1.00 & 1.00 & 2.00 & 2.00 \\
Bone meal & 2.00 & 2.00 & 0.25 & 0.25 \\
Sodium chloride & 0.25 & 0.25 & 0.20 & 0.20 \\
Lysine & 0.20 & 0.20 & 0.20 & 0.20 \\
Methionine & 0.20 & 0.20 & 0.25 & 0.25 \\
Vitamin/mineral premix * & 0.25 & 0.25 & 100.00 & 100.00 \\
Total & 100.00 & 100.00 & & \\
Nutrient composition (calculated) & & & & 21 \\
Crude protein (\%) & & & 21 & 3000 \\
Metabolisable energy (kcal/kg) & 21 & 21 & 3000 & 5.95 \\
Ether extract (\%) & 3000 & 3000 & 8.71 & 6.10 \\
Crude fibre (\%) & 5.65 & 8.44 & 6.2 & 1.40 \\
Calcium (\%) & 5.06 & 5.49 & 1.40 & 1.2 \\
Available phosphorus \% & 1.32 & 1.32 & 1.2 & \\
\hline
\end{tabular}

Note: Each kilogram contains Vit A 3600,000 IU. Vit. $D_{3} 600.000$ IU. Vit E 4.000.000 mg. Vit $B_{1}-B_{6} 640,1600,600,4.00$ mg. Panthothenic acid 2000 mg, Biotin $300 \mathrm{mg}$. Manganese $16000 \mathrm{mg}$. Manganese $16000 \mathrm{mg}$. Selenium $80 \mathrm{mg}$. Vit. K $600 \mathrm{mg}$. Cobalt $80 \mathrm{mg}$. Copper1200 $\mathrm{mg}$. Zinc 12,000mg. Folic acid $200 \mathrm{mg}$. Choline chloride700000 mg. Antioxidant $500 \mathrm{mg}$.

Table 4. Growth performance of broiler chickens fed diets containing different protein sources (1-5 weeks of age).

\begin{tabular}{lccccc}
\hline \multirow{2}{*}{ Parameters } & \multicolumn{3}{c}{ Diets } & \multirow{2}{*}{ SEM } \\
\cline { 2 - 5 } & T1 [GNC] & $\begin{array}{c}\text { T2 [Soya bean } \\
\text { (Cooked)] }\end{array}$ & $\begin{array}{c}\text { T3 [ALBS (Salt- } \\
\text { treated)] }\end{array}$ & $\begin{array}{c}\text { T4 [Bambara nut } \\
\text { (Sprouted)] }\end{array}$ & \\
\hline Daily feed intake $(\mathrm{g})$ & 53.40 & 70.40 & 69.00 & 67.60 & $17^{*}$ \\
Daily weight gain (g) & 26.76 & 35.14 & 32.11 & 30.24 & $8.38^{*}$ \\
Feed conversion ratio & 1.82 & 1.89 & 2.04 & 2.55 & $0.73^{*}$ \\
Feed efficiency ratio & 0.50 & 0.50 & 0.52 & 0.40 & $\mathrm{NS}^{*}$ \\
Survivability (\%) & 99.60 & 99.80 & 99.80 & 100 & $\mathrm{NS}$ \\
\hline
\end{tabular}

enhanced in the birds fed African locust bean (ALBS) (0.52). The survivability of the birds is more effective in Bambara nut based diet (100\%) and lower in GNC based diet but the values are statistically similar $(p>0.05)$. At the finisher phase birds fed soybean-based diet had higher feed intake compared to other protein sources $(p<0.05)$. The daily weight gain was highest in the soybean diet $(73.35 \mathrm{~g})(\mathrm{p}<0.05)$ (Table 5) and is a reflection of high feed intake $(p<0.05)$. The feed conversion ratio was better in the soybean based diet $(p<0.05)$ and is a reflection of high feed intake and high body weight gain $(p<0.05)$. This finding is in line with the findings of Aguihe et al. (2011) on the superiority of soybean on other plant protein sources. Adeniyi (2008) asserted that feed intake and body weight gain are determinants of quality feeds. The feed efficiency ratio was better in the soybean and Bambara nut based diets $(0.87 ; p<0.05)$. At the overall performance, daily feed intake $(70.20-80.95 \mathrm{~g})$, daily weight gain $(34.48-53.60 \mathrm{~g})$, feed conversion ratio (1.51-1.68) and feed efficiency ratio $(0.60-0.66)$ are affected by the dietary protein source $(p<0.05)$ with soybean based having enhanced performance (Table 6). 
Table 5. Growth performance of broiler chickens fed diets containing different protein sources (5-8 weeks of age).

\begin{tabular}{lccccc}
\hline & \multicolumn{4}{c}{ Diets } & \multirow{2}{*}{ SEM } \\
\cline { 2 - 5 } Parameters & T1 [GNC] & $\begin{array}{c}\text { T2 [Soya bean } \\
\text { (Cooked)] }\end{array}$ & $\begin{array}{c}\text { T3 [ALBS } \\
\text { (Salt-treated)] }\end{array}$ & $\begin{array}{c}\text { T4 [Bambara } \\
\text { nut (Sprouted)] }\end{array}$ & \\
\hline Daily weight gain (g) & 77.51 & 83.98 & 81.51 & 79.22 & $6.47^{*}$ \\
Daily weight gain (g) & 60.27 & 73.35 & 69.94 & 69.05 & $13.08^{*}$ \\
Feed conversion ratio & 1.43 & 1.15 & 1.17 & 1.15 & $0.28^{*}$ \\
Feed efficiency ratio & 0.70 & 0.87 & 0.86 & 0.87 & $0.17^{*}$ \\
Survivability (\%) & 99.80 & 100 & 99.60 & 100 & NS \\
\hline
\end{tabular}

Table 6. Pooled performance of broiler chickens fed diets containing different protein sources (1-8 weeks of age).

\begin{tabular}{lccccc}
\hline \multirow{2}{*}{ Parameters } & \multicolumn{4}{c}{ Diets } & \multirow{2}{*}{ SEM } \\
\cline { 2 - 5 } & T1 [GNC] & $\begin{array}{c}\text { T2 [Soya bean } \\
\text { (Cooked)] }\end{array}$ & $\begin{array}{c}\text { T3 [ALBS (Salt- } \\
\text { treated)] }\end{array}$ & $\begin{array}{c}\text { T4 [Bambara nut } \\
\text { (Sprouted)] }\end{array}$ & \\
\hline Daily feed intake (g) & $70.20^{\mathrm{b}}$ & $80.95^{\mathrm{a}}$ & $80.41^{\mathrm{a}}$ & $78.80^{\mathrm{a}}$ & $2.34^{*}$ \\
Daily weight gain (g) & $34.48^{\mathrm{b}}$ & $53.60^{\mathrm{a}}$ & $47.96^{\mathrm{a}}$ & $50.03^{\mathrm{a}}$ & $11.57^{*}$ \\
Feed conversion ratio & $1.67^{\mathrm{a}}$ & $1.51^{\mathrm{b}}$ & $1.68^{\mathrm{a}}$ & $1.58^{\mathrm{ab}}$ & $0.09^{*}$ \\
Feed efficiency ratio & $0.60^{\mathrm{c}}$ & $0.66^{\mathrm{a}}$ & $0.60^{\mathrm{c}}$ & $0.63^{\mathrm{b}}$ & $0.03^{*}$ \\
Survivability (\%) & 99.80 & 100 & 99.80 & 99.60 & - \\
\hline
\end{tabular}

Means bearing superscripts within the same raw are statistically different $(p<0.05)$.

Table 7. Carcass yield, organs weight and gut characteristics (\% live weight) of broiler chickens fed diets containing different protein sources.

\begin{tabular}{|c|c|c|c|c|c|}
\hline \multirow[b]{2}{*}{ Parameters } & \multicolumn{4}{|c|}{ Diets } & \multirow[b]{2}{*}{ SEM } \\
\hline & T1 [GNC] & $\begin{array}{c}\text { T2 [Soya bean } \\
\text { (Cooked)] }\end{array}$ & $\begin{array}{c}\text { T3 [ALBS (Salt- } \\
\text { treated)] }\end{array}$ & $\begin{array}{c}\text { T4 [Bambara } \\
\text { nut (Sprouted)] }\end{array}$ & \\
\hline Live weight (g) & $1988.00^{b}$ & $2160.00^{a}$ & $1920.00 \mathrm{~b}$ & $1850.00^{c}$ & $127^{*}$ \\
\hline Slaughter weight (g) & $1610.00^{c}$ & $1965.00^{a}$ & $1747.00^{\mathrm{b}}$ & $1702.00^{b}$ & $103^{*}$ \\
\hline Plucked weight (g) & 1600.00 & 1814.00 & 1651.00 & 1573.00 & $100^{*}$ \\
\hline Dressing percentage (\%) & 81.31 & 83.31 & 85.46 & 86.25 & $11.75^{\mathrm{NS}}$ \\
\hline Abdominal fat $(\%)$ & $0.64^{a}$ & $0.60^{d}$ & $0.61^{c}$ & $0.62^{b}$ & $0.01^{*}$ \\
\hline Gizzard (\%) & 1.77 & 1.61 & 1.64 & 1.63 & $0.09^{*}$ \\
\hline Heart (\%) & 0.24 & 0.22 & 0.23 & 0.22 & $0.08^{\mathrm{NS}}$ \\
\hline Liver (\%) & 1.21 & 1.21 & 1.22 & 1.22 & $0.01^{\mathrm{NS}}$ \\
\hline Lungs (\%) & 0.30 & 0.32 & 0.32 & 0.32 & $0.003^{\mathrm{NS}}$ \\
\hline Pancreas (\%) & 0.24 & 0.22 & 0.23 & 0.22 & $0.003^{\mathrm{NS}}$ \\
\hline Small intestine (\%) & 1.22 & 0.40 & 0.40 & 0.40 & $0.005^{\mathrm{NS}}$ \\
\hline Large intestine (\%) & 3.30 & 2.66 & 3.22 & 3.23 & $0.002^{\mathrm{NS}}$ \\
\hline Caeca $(\%)$ & 1.14 & 1.16 & 1.18 & 1.18 & $0.008^{\mathrm{NS}}$ \\
\hline Small intestine $(\mathrm{cm})$ & $40.80^{b}$ & $43.20^{\mathrm{a}}$ & $40.80^{\mathrm{b}}$ & $41.80^{\mathrm{a}}$ & $1.98^{*}$ \\
\hline Large intestine $(\mathrm{cm})$ & 201.60 & 144.20 & 141.80 & 142.40 & $90.2^{*}$ \\
\hline
\end{tabular}

$\mathrm{SEM}=$ Standard error of means, $\mathrm{abc}=$ Means bearing different superscripts within the same row are statistically different $(p<0.05)$. NS=not significant.

The carcass yield and gut characteristics is shown in Table 7 while the cut of parts is shown in Table 8 . Results showed that live weight $(1988-2160 \mathrm{~g})$, slaughter weight (1610-1965 g) and plucked weight (1600-1814 g) (Table 7) were significantly $(p<0.05)$ affected by different plant protein sources. The higher live weight, slaughter weight and pluck weight of broilers fed full fat soybean based diet can be attributed to high quality and nutritional attributes 
Table 8. Cut up parts (\% carcass weight) of broiler birds fed different protein sources.

\begin{tabular}{lccccc}
\hline \multirow{2}{*}{ Parameters } & \multicolumn{5}{c}{ Diets } \\
\cline { 2 - 5 } & T1 [GNC] & $\begin{array}{c}\text { T2 [Soya bean } \\
\text { (Cooked)] }\end{array}$ & $\begin{array}{c}\text { T3 [ALBS (Salt- } \\
\text { treated)] }\end{array}$ & $\begin{array}{c}\text { T4 [Bambara nut } \\
\text { (Sprouted)] }\end{array}$ & SEM \\
\hline Neck & $3.50^{\mathrm{b}}$ & $3.93^{\mathrm{a}}$ & $3.37^{\mathrm{b}}$ & $3.40^{\mathrm{b}}$ & $0.23^{\star}$ \\
Wings & $7.18^{\mathrm{b}}$ & $8.09^{\mathrm{a}}$ & $7.47^{\mathrm{b}}$ & $7.17^{\mathrm{b}}$ & $0.32^{\star}$ \\
Back & $8.34^{\mathrm{b}}$ & $9.06^{\mathrm{a}}$ & $8.51^{\mathrm{b}}$ & $8.32^{\mathrm{b}}$ & $0.42^{*}$ \\
Thigh & $18.23^{\mathrm{b}}$ & $19.30^{\mathrm{a}}$ & $18.44^{\mathrm{b}}$ & $18.14^{\mathrm{b}}$ & $0.29^{\star}$ \\
Breast & $19.68^{\mathrm{a}}$ & $20.34^{\mathrm{a}}$ & $19.42^{\mathrm{b}}$ & $19.32^{\mathrm{b}}$ & $0.95^{\star}$ \\
\hline
\end{tabular}

$\mathrm{SEM}=$ Standard error of means, abc= Means bearing different superscripts within the same row are statistically different $(p<0.05)$.

Table 9. Economics of production of broiler chickens fed different protein sources.

\begin{tabular}{lcccc}
\hline & \multicolumn{4}{c}{ Diets } \\
\cline { 2 - 5 } Parameters & T1 [GNC] & $\begin{array}{c}\text { T2 [Soya bean } \\
\text { (Cooked)] }\end{array}$ & $\begin{array}{c}\text { T3 [ALBS (Salt- } \\
\text { treated)] }\end{array}$ & $\begin{array}{c}\text { T4 [Bambara } \\
\text { nut (Sprouted)] }\end{array}$ \\
\hline Initial weight $(\mathrm{g})$ & 98.62 & 97.15 & 99.25 & 99.78 \\
Final weight $(\mathrm{g})$ & 1610.00 & 1965.00 & 1747.00 & 1702.00 \\
Total feed intake $(\mathrm{kg})$ & 3.93 & 4.53 & 4.50 & 4.41 \\
Feed cost (A/kg) & 77.76 & 83.73 & 80.73 & 84.63 \\
Total feed cost $(\mathrm{N})$ & 305.60 & 379.30 & 363.29 & 372.22 \\
Total weight gain $(\mathrm{kg})$ & 1.93 & 3.00 & 2.69 & 2.80 \\
Feed cost (A/kg) gain & 158.34 & 126.43 & 135.05 & 133.29 \\
\hline
\end{tabular}

*Based on prevailing market price.

of full fat soybean (Olomu, 1995, Iwe, 2005). The dressing percentage $(83.31-86.25 \%)$ are not affected by different protein sources $(p>0.05)$. Similarly, the heart $(0.22$ $0.24 \%)$, liver $1.21-1.22 \%)$, lungs $(0.30-0.32 \%)$, pancreas $(0.22-0.24 \%)$, small intestine $(0.40-1.22 \%)$, large intestine (2.66-3.30\%) and caeca (1.14-1.18\%) followed the same trend being similar $(p>0.05)$. The abdominal fat $(0.61-$ $0.64 \%)$, gizzard (1.61-1.77\%), small intestine (40.80-43.20 $\mathrm{cm})$ and large intestine $(141.80-201.60 \mathrm{~cm})$ are affected by the different protein sources $(p<0.05)$ (Table 7$)$. The percentage of cut up parts affected include neck (3.37$3.90 \%)$, wings $(7.17-8.09 \%)$, back (8.32-9.06 \%), thigh (18.14-19.30\%) and breast (19.32-20.34\%) (Table 8. The dressing percentage did not affect the different protein sources $(p>0.05)$. Higher abdominal fat and gizzard $(p<0.05)$ reported in GNC based diet suggest a poor carcass quality (Medugu et al., 2010). Most of the internal organs (liver, lungs, small intestine and large intestine) were not affected by the different protein sources ( $p>0.05)$. All the prime cuts were significantly $(p<0.05)$ affected by the dietary protein sources, the neck, wings, back and thigh were lower in GNC based diet $(p<0.05)$ and were higher in soybean based diet. The reduced weight of these organs can be attributed to proper utilization of soybean to build these organs, coupled by the fact that soybean has high biological value compared to other protein sources.

The economics of production revealed that the feed cost per $\mathrm{kg}$ gain is highest in GNC based diet ( 158.34$)$ and lowest in soya bean-based diet ( 126.43) diet (Table 9). The reduced feed cost in the GNS diet can be attributed to lack of additional cost of processing. The total feed cost was highest in soybean-based diet. The feed cost per $\mathrm{kg}$ gain is highest in the GNS diet (158.34) and lowest in soybean-based diet (126.43). The soybean-based diet is the least cost diet having the lowest cost of gain.

\section{Conclusion}

The growth response of broiler chickens fed different protein sources are satisfactory, however broilers fed soybean-based diet proved to be more efficient in enhancing the performance parameters with concomitant reduction in price.

\section{CONFLICTS OF INTEREST}

The authors declare that they have no conflict of interest.

\section{REFERENCES}

Adeniyi, A. A. (2008). Replacement value of soybean meal with groundnut cake with or without fish meal supplementation in diet of pullet chick. Journal of Applied Science Research, 4(10), 1249-52. 
Aguihe, P. C., Kehinde, A. S., Fatokun, B. O., Lekene, B., \& Adelekan, K. M. (2011). Growth performance and cost implication of utilizing local processed groundnut cake in cockerel starter diet as a replacement for soybean. In: Adeniji, A. A., Olatunji, E. A., \& Gana, E. S. (eds.). Value re-orientation in animal production: A key to national food security and sustainable economy. Pp. 368-371. Proceedings of 36th Annual Conference of Nigerian society of animal production. 13th-16th March, 2011.

Akure, C. O., Abeke, F. O., \& Abdullahi, A. U. (2021). Performance of broiler starter chicks fed graded dietary levels of toasted Mucuna pruriens seed meal as a protein source. Proceedings of 26th Annual Conference of ASAN-NIAS, Uyo, Nigeria.

Ani, A. O., Amalu S. N., Ugwuowo L. C., \& Osita C. O. (2012). Effect of graded levels of toasted bambara nut offal and supplementary enzyme on heamatological parameters and organ weights of haco-cockerels. Global Journal of Bioscience and Biotechnology. 1(1), 6-11.

Association of Official Analytical Chemist (AOAC) (1990). Official Methods of analysis 15th Edition. Washington DC.

Ari, M.M., Ayanwale, B.A., Adama, T.Z. and Olatunji, E.A. (2012). Effects of different fermentation methods on the proximate composition, amino acids profile and some antinutritional factors in soybaean (Glycine max). Fermentation Technology and Bioengineering, 2, 6-13.

Bura, A. B. (2000). The role small scale industries on socioeconomic development of Azare. Nigerian Certificate in Education Project College of Education, Azare, Bauchi State.

Duncan's Multiple range test (1955). A biometric Approach.

Etuk, E. B., Ifeduba, A. V., Okata, U. E., Chiaka, I., Okoli, I. C., Okeudo, N. J., Esonu B. O., Udedibie A. B. I., \& Moreki, J. C. (2012). Nutrient composition and feeding value of sorghum for livestock and poultry: A review. Journal of Animal Science Advances, 2(6), 510-524.

FAOSTAT (2018). Food and Agriculture Organization of the United Nations.

Food and Agricultural Organization (FAO) (1993). FAO Production year book, 46. United Nations Rome.

Iwe, M. O. (2003). The science and technology of soya bean, chemistry nutrition, processing and utilization. Rejoint Communication Services Ltd. Pp.1-31.

Maidala, A., \& Istifanus, J. A. (2012). The role of micro livestock in alleviating protein deficiency and poverty reduction in Nigeria. In: Dantata, I. J., Maidala, A., \& Garba, A.R. (eds.). Proceedings of 2nd National conference of school of vocational and technical education, College of Education Azare, Bauchi State.

Maidala, A., Doma, U. D., Egbo, L. M., Mohammed, A., \& Kalla, D. J. U. (2015). Effects of different processing methods of bambaranut (Vigna subterranean (I.) Verdc) on cuts of parts of broiler chickens. In: Adeyinka, I. A., Kabir, M., Abdu, S. B., Erakpotobor, G. I., Hassan, M. R., \& Iyiola-tunji A. O. (eds.). Paper presented in NSAP, 10th May, 2015, ABU Zaria.

Maidala, A. (2015). Nutritional evaluation of selected plant protein sources in the diets of broiler chickens. Ph.D. Thesis, Abubakar Tafawa Balewa University Bauchi.

Maidala, A., Doma, U. D., \& Egbo, L. M. (2017). Effects of processing methods of soya bean (Glycine max (I) merrill) on carcass yields and organs weight of broiler chickens. FUDMAJournal of Agriculture and Agric. Tech., 3(1), 49-56.
Maidala, A., Doma, U. D., Egbo, L. M., Makinde, O. J., Adejumo, I. O., Chana, I. M., \& Duniya, A. M. (2018). Response of broiler finisher chickens to diets containing differently processed African locust bean seeds. In: Okoli, I. C., Ogbuewu, I. P., Emenalom, O. O., Esonu, B. O. (eds.). Nigerian society for Animal Production on 18th -22nd March, 2018 at New SAAT Lecture Theatre, Federal University of Technology Owerri, Imo State. Pp. 1207-1210.

Maidala, A., Egbo. M. L., \& Doma, U. D. (2013). Effects of different processing methods on the chemical composition and antinutritional factors of soybean (Glycine max (I.) Merrill). Pakistan Journal of Nutrition, 12(12), 1057-1060.

Maidala, A., Zagi, S. P., \& Ajighjigh, D. T. (2011). Performance of weaner rabbits fed graded levels of toasted bambaranut (Vigna subterranean (L.) Verdc) as a partial replacement for soybean. Journal of Environment, Technology and Sustainable Agriculture, 1(1), 128-13

Medugu, C. I., Kwari, I. D., Igwebuike, J., Nkama, I., Mohammed, I. D., \& Hamaker, B. (2010). Performance and economics of production of broiler chickens fed sorghum or millet as replacement for maize. Agriculture and Biology Journal of north America, 1(3), 321-325.

Medugu, C. I., Saleh, B., Igwebuike, J. U., \& Ndirmbita, R. L. (2012). Strategies to improve the utilization of tannin-rich feed materials by poultry. International Journal of Poultry Science, 11(6), 417-423.

Obun, C. O. (2007). Performance and some heamatological response of finisher broilers fed graded levels of fermented locust bean (Parkia biglobosa) seeds meal. Asian Journal of Agricultural Research, 1, 125-130.

Olomu, J. M. (1995). Monogastric nutrition, principles and practice. Jachen Publication, 320pp.

Oluyemi, J. A., \& Roberts, F. A. (2000). Poultry production in warm wet climates, Macmillan Press, Ltd, London. Pp. 195199.

Sahel, C. P. (2015). An assessment of the Nigerian poultry sector. Sahel Capital Partners \& Advisory Limited: Lagos, Nigeria. Retrieved from https://sahelconsult.com/wpcontent/uploads/2019/06/Sahel-Newsletter-Volume-11.pdf.

Sanni, S. A., \& Ogundipe, S. O. (2005). Economics of some modules of poultry production in Kaduna state. Nigerian Journal of Animal Production, 32(1), 102-107.

Shaahu, D. T., Ikurior, S. A., \& Tiough, S. M. (2011). Effect of replacing dietary full fat soybean with raw decorticated and cooked lablab seeds on performance of weaner rabbits. In: Adeniji, A. A., Olatunji, E. A., \& Gana, E. S. (eds.). Value Reorientation in animal production: A key to national food security and sustainable economy. Pp.368-371. Proceedings of 36th Annual Conference of Nigerian society of animal production. 13th-16th March, 2011.

Steel, R. G. D., \& Torrie, J. H. (1980). Principles and Procedures of Statistics, 2nd edition published by McGraw Hill books Co. New York, USA. 